\title{
Reviews
}

\section{HAPLOTYPES AFFECTING FERTILITY IN HOLSTEIN CATTLE}

\author{
(review)
}

\begin{abstract}
N.A. ZINOVIEVA
L.K. Ernst All-Russian Research Institute of Animal Husbandry, Federal Agency of Scientific Organizations, pos. Dubrovitsy, Podolsk Region, Moscow Province, 142132 Russia, e-mail n_zinovieva@mail.ru Acknowledgements:

The studies were performed with financial support of the Russian Ministry of Education and Science; project № 14.604.21.0062, unique identification № RFMEFI60414X0062

Received April 30, 2016
\end{abstract}

\section{Abstract}

The observed progressive increase of homozygosity in the cultural cattle breeds leads to increased negative impact of LoF-mutations ( $\mathrm{LoF}$ - loss-of-function) in reducing cow fertility. Significant progress in the identification of LoF-mutations, which are associated with fertility, was achieved with the development of a new approach called «homozygosity mapping» (C. Charlier et al., 2008). This approach allows identifying the chromosomal regions characterized by loss of homozygosity, which are the candidate regions for location of fertility haplotypes associated with embryonic and early post-embryonic mortality. In the past few years, the fertility haplotypes were identified in almost all the major breeds of dairy cattle: Holstein (P.M. VanRaden et al., 2011; S. Fritz et al., 2013; T.A. Cooper et al., 2013), Jersey (P.M. VanRaden et al., 2011; T.S. Sonstegard et al., 2013), Brown Swiss (P.M. VanRaden et al., 2011; T.A. Cooper et al., 2013; M. McClure et al., 2013), Montbeliarde (S. Fritz et al., 2013), Ayrshire (T.A. Cooper et al., 2013), Fleckvieh (H. Pausch et al., 2015), Nordic Red cattle (N.K. Kadri et al., 2014). In presented review, it is characterized the haplotypes affecting fertility, which are segregated in Holsteins - the main dairy cattle breed worldwide (bred in 161 countries). In Russia, the ratio of Holstein and holsteinized Black-Pied cattle accounted for more than $65 \%$ of common dairy cattle population. Currently, in the Holstein breed is registered ten fertility haplotypes (HCD, HH0, HH1, HH2, HH3, HH4, HH5, HHB, HHC, HHD), which affect the pregnancy losses and/or associated with embryonic and early post-embryonic mortality at different stages (J.B. Cole et al., 2016). Possible causes for segregation of the fertility haplotypes in cattle populations are discussed. These are intensive use of carrier bulls for artificial insemination, a considerable period from occurrence to the identification of causative mutations (18-59 years), the possible association of carrier status with productive traits. The chromosomal location of the fertility haplotypes is characterized, the haplotype frequencies in North-American Holstein population are presented and the effects of bull carrier status on cow pregnancy rate are shown. It is described the stages of pregnancy and/or the age of calves on which there is the embryonic mortality of affected fetus and/or the death of affected calves. It is characterized the genes and the causative LoFmutations, which are associated with fertility haplotypes. It is shown that more than $5 \%$ of sires used in Russia have had the fathers, which are the carriers of fertility haplotypes. Thus, it is necessary to screen the Russian population of Holstein and holsteinized cattle to detect the carrier status of animals. The role of DNA-diagnostics in the control and elimination of fertility haplotypes and associated genetic defects in the Russian population of breeding cattle is discussed. Survey for these latent genetic defects among domestic Holstein and holsteinized Black Pied cattle showed that they occur at a relatively high rate, reaching about $10 \%$ for cows and about $4 \%$ for bulls. Among the bulls more than $5 \%$ were hidden CVM carriers, and about $3 \%$ were latent BLAD carriers. Currently, due to genetic monitoring, these mutant alleles are not being recorded in sires of the population.

Keywords: Holstein breed, embryonic mortality, genetic defects, fertility haplotype

Holstein cows are used for milk production around the world. According to the FAO (Food and Agriculture Organization), they are bred at least in 161 countries [1]. Holstein and Holsteinized Black Pied breeds account for more than $65 \%$ of the total dairy livestock in Russia [2].

However, with constant progressive growth of milk production in Holstein cows, there is a decrease in reproductive potential [3]. For example, in the 
US population of Holstein cows from 1976 to 1999, the service period [the period from the offspring birth to the first effective insemination] prolonged from 126 to 169 days [4]; from 1970 to 2000 , the number of inseminations required to achieve pregnancy increased from 1.8 to 3.0 , and the interval between calvings increased 'from 13.5 to 14.9 months [5]; from 1972 to 1996, the proportion of pregnancies after the first insemination decreased from 62 to $34 \%$ [6].

In Russia, the frequency rate of pregnancies in cows after the first insemination is 40-50\% [7]. Until recently, the decline in reproductivity has been associated mainly with puerperal problems of clinical nature, as well as with the development of metabolic stress caused by lactation. Currently, it is believed that at least half of such a decline is due to genetic factors $[5,8,9]$.

Investigation of several hundred human genomes using the NGStechnology (new generation sequencing) demonstrated that an average genome typically carries 250-300 of sequence variants with some dysfunction (LoF, lossof-function variants), 50-100 of which are localized in the genes of the diseases $[10,11]$ and about 20 of them are completely inactivated genes [12]. Similar diversity in the human and cattle genomes suggests the presence of approximately equal numbers of LoF-mutations in the genome of the latter [13].

This review summarizes the results of studies on the identification of LoF-mutations in Holstein cattle, which are associated with embryonic and early post-embryonic mortality and designated as haplotypes affecting fertility. The discovery of a number of LoF-mutations was possible owing to the development and use of a new approach, the so-called homozygosity mapping.

Increased adverse effects of LoF-mutations on fertility in cows are associated with the progressive increase in homozygosity in stud breeds, as such mutations in the homozygous state may be fatal, resulting in fetal death. Thus, an average coefficient of inbreeding in Holstein cattle in the US has increased from $0.22 \%$ in 1965 to $6.53 \%$ in 2015 [14]. Among causes of the increased level of inbreeding there are i) a relatively low initial genetic diversity in most dairy breeds as all of them originated from a limited number of breeders, ii) the extensive use of a relatively small number of outstanding sires for artificial insemination, practiced for more than 50 years, and iii) the strictly limited selection for a limited number of traits [15]. Some Holstein bulls became fathers of several thousand sons, evaluated for the quality of the offspring, and several hundred thousands or even more than a million of lactating daughters. Furthermore, among approximately 5,000 bulls evaluated annually for the quality of the offspring, almost $50 \%$ are descendants of 10 most popular bulls [16]. In this regard, the diagnosis of LoF-mutations associated with fatal hereditary diseases, is becoming one of the key elements in genetic monitoring of the livestock populations $[17,18]$.

Until recently, the number of LoF-mutations, which are responsible for hereditary disorders and cause embryonic and early post-embryonic mortality, in dairy cattle has been limited to a couple of mutations. Thus, some LoFmutations have been identified in Holstein cattle, causing the following hereditary diseases: deficiency of uridine monophosphate synthase (DUMPS) [19], bovine leukocyte adhesion deficiency (BLAD) [20], complex vertebral malformation (CVM) [21], brachyspina syndrome (BY) [22]; Weaver syndrome in the Brown Swiss breed was associated with the manifestation of LoF-mutations [23].

Considerable progress in the identification of LoF-mutations, associated with fertility, has been achieved with the development of a new approach called homozygosity mapping. It is based on the genotyping tens of thousands of SNPs (single nucleotide polymorphism) using chips of medium and high density with 
subsequent identification of the regions with loss of homozygosity, i.e. characterized by the absence of one of the homozygous genotypes. The Bovine SNP50 v2 BeadChip (Illumina, USA) chip, which allows to assess 54,609 SNPs, may serve as an example.

These genome segments are considered the candidate regions for the localization of genes, which are carriers of LoF-mutations. The proposed approach allows identifying fatal genetic defects in a very short period of time and in the presence of a limited number of clinical cases [24]. In the past few years, the new approach allowed to identify these defects almost in all major breeds of dairy cattle, such as Holstein [25-27], Jersey [25, 28], Brown Swiss [25, 27, 29], Montbéliarde [26], Ayrshire [27], Simmental [30], and in the Nordic Red cattle [31]. Defects identified using the homozygosity mapping technique were designated as fertility haplotypes. Such previously known genetic defects as DUMPS, BLAD, CVM and brachyspina were also confirmed using this method. If a DNA chip is used in the diagnosis of genetic defects, the results are interpreted as the identification of the relevant haplotypes (HHD, HHB, HHC, HH0), while in the direct assay of the causal mutations it comes to identifying actual genetic defects.

Currently, there are ten fertility haplotypes (HCD, HH0, HH1, HH2, $\mathrm{HH} 3, \mathrm{HH} 4, \mathrm{HH} 5, \mathrm{HHB}, \mathrm{HHC}, \mathrm{HHD})$ registered in the Holstein breed, which influence the proportion of successful inseminations (resulting in pregnancy) and/or are associated with embryonic and early post-embryonic mortality at different stages, with the incidence at 0.01 to $2.95 \%$ (Fig. 1). Negative impact of these haplotypes, assessed in the population of North American Holsteins, is manifested by reductions in the rates of inseminations resulted in pregnancy (when mating cows, whose fathers were hidden carriers of the haplotype, with the bulls containing the same haplotype in the genome) by 1.0-9.9 \% [25-27].

A

\begin{tabular}{|c|c|c|c|c|c|c|}
\hline \multirow{9}{*}{$\begin{array}{llll}\mathrm{d} & \mathrm{c} \\
\end{array}$} & & - & $-1,9 \ldots-6,7 \%$ & $-1,0 \%$ & $-2,9 \%$ & н.Д. \\
\hline & & $2,50 \%$ & $2,76 \%$ & $0,25 \%$ & $1,37 \%$ & $0,01 \%$ \\
\hline & & BTA11 & BTA21 & BTA1 & BTA3 & BTA1 \\
\hline & & $\mathrm{HCD}$ & НH0 & HHB & $\mathrm{HHC}$ & HHD \\
\hline & $\mathrm{a}$ & & & & & \\
\hline & & НН1 & $\mathrm{HH} 2$ & НН3 & $\mathrm{HH} 4$ & HН5 \\
\hline & & BTA5 & BTA1 & BTA8 & BTA1 & BTA9 \\
\hline & & $1,92 \%$ & $1,66 \%$ & $2,95 \%$ & $0,37 \%$ & $2,22 \%$ \\
\hline & & $-3,1 \ldots-9,9 \%$ & $-0,8 \ldots-4,3 \%$ & $-3,2 \ldots-5,5 \%$ & $-1,7 \ldots-5,8 \%$ & $-3,5 \%$ \\
\hline
\end{tabular}

B

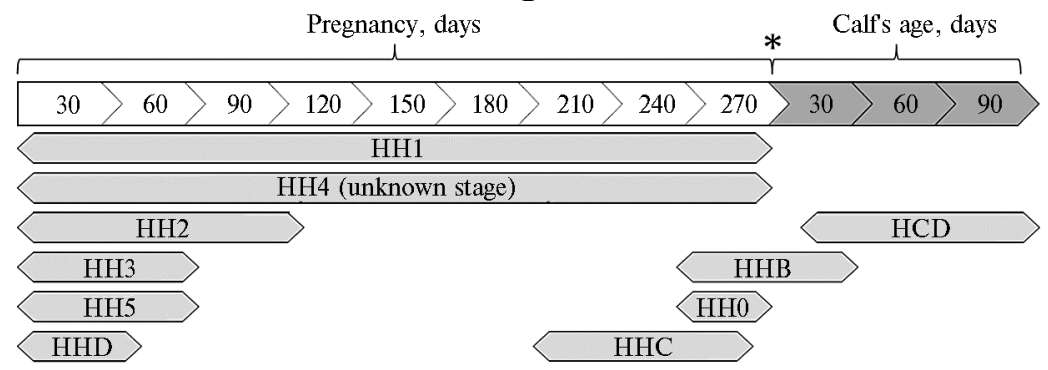

Fig. 1. Summary of fertility haplotypes in Holstein cattle

A. Chromosomal localization, distribution and phenotypic expression of fertility haplotypes in Holstein cattle: $a-$ fertility haplotypes in Holstein cattle; b - Bos taurus autosome (BTA), which harbors genes associated with fertility haplotypes; c - haplotype frequency (which is $1 / 2$ of the number of hidden carriers) in the North American Holstein population; $d$ - decrease in the frequency of pregnancy in cows, whose fathers were hidden defect carriers, when mated with the bulls being hidden carriers of a similar defect, as calculated for the North American and French 
Holstein populations. A dash means that the pregnancy is progressing normally, and the calf death occurs within 1-2 months of life; н.д. - not diagnosed.

B. A diagram of the timing of fetal death (calves) - homozygous carriers of haplotypes fertility. Pregnancy term in cows-mothers is shown on a white-filled scale, starting with insemination (taken as day 0); calving date is marked with an asterisk. Scale reflecting the age of the calf starts from the date of calving (taken as day 0 ) and is grey filled. Fertility haplotypes (HCD, HH0, $\mathrm{HH} 1, \mathrm{HH} 2, \mathrm{HH} 3, \mathrm{HH} 4, \mathrm{HH} 5, \mathrm{HHB}, \mathrm{HHC}, \mathrm{HHD})$ are given inside the arrows, the location of which relative to the pregnancy term scale and the calf age scale indicates a probable time of the death of the fetus or calf, homozygous for the respective haplotype.

The spread of fertility haplotypes is promoted by the fact that their carriers are outstanding sires, which are preferred to be used in the system of artificial insemination. For example, famous bull Carlin-M Ivanhoe BELL appeared to be a hidden carrier of HHB and HHC haplotypes. However, only in the United States, there are more than 79,000 of lactating daughters and more than 1,200 evaluated sons obtained from him [33].

The carriers of the HH1 haplotype were two sires extensively involved in the reproduction: Pawnee Farm Arlinda CHIEF (year of birth 1962) and his son Walkway Chief MARK (year of birth 1978). The latter gave more than 60,000 of daughters and sons, who became actively used sires [34]. It was found that each of these two bulls was associated with about $7 \%$ allele pool of the modern North American Holstein population [35].

The wide spread of the HH4 haplotype occurred through a French bull JOCKO BESNE, who gave more than 1.7 million of semen doses. The databases of Holstein cattle in 21 countries contain register entries on the productivity of more than 160,000 of his daughters. There are more than 23,000 farms in France, where daughters of JOCKO BESNE are used [36].

Another reason for the accumulation of fertility haplotypes in cattle populations is a long time (18-59 years), which it takes from the occurrence of mutations to their identification and the development of test kits for screening and detection of hidden carriers [Fig. 2].

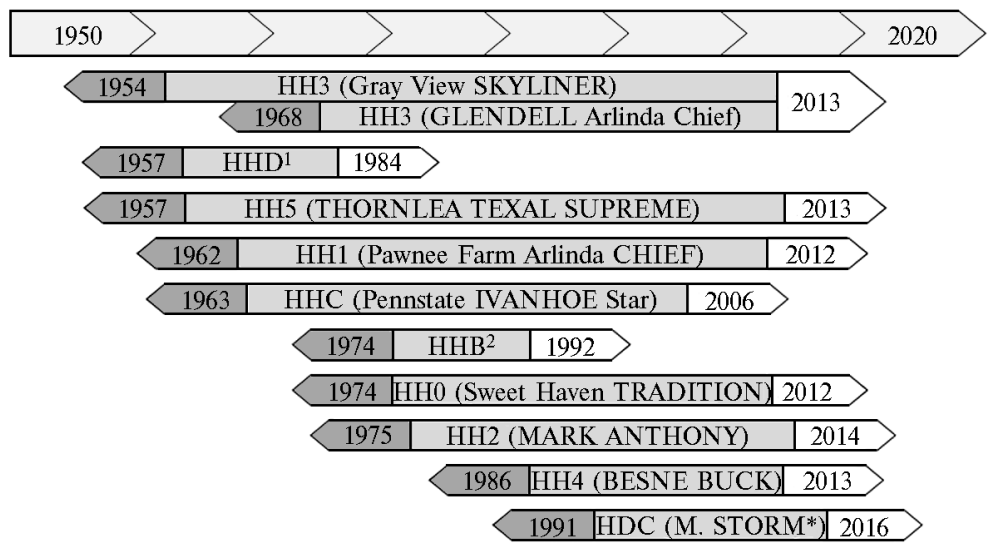

Fig. 2. Time from birth of Holstein bulls, who were parents of haplotypes affecting fertility before the relevant mutations were identified. For each haplotype, the arrow is oriented along the timeline (above) from the bull-parent's year of birth (left) to the year when the relevant mutation was identified (right). The name of the haplotype is given in brackets in the central part of the arrow indicating the nickname of the corresponding bull-parent $\left(\mathrm{HHD}^{1}-\right.$ Skokie Sensation NED; HHB ${ }^{2}-$ Carlin-M Ivanhoe BELL). An asterisk denotes the earliest characterized carrier of the mutation (the exact originator is unknown).

Possible associations between haplotypes affecting fertility and the productive qualities can be considered a further reason for their spread. Thus, the analysis of $\sim 3$ million registry entries of productivity parameters in 1.7 million daughters of bulls with known genotypes for HHC demonstrated that daughters 
of bulls, who were hidden HHC carriers, had higher milk yield (higher by $160 \mathrm{~kg}$ on average) and higher yields of milk fat (by $4 \mathrm{~kg}$ ) and protein (by $5 \mathrm{~kg}$ ) [37]. Currently, genes and precise localization of the relevant LoF-mutations for nine haplotypes affecting fertility in Holstein cattle have been established (Table).

Genes and relevant LoF-mutations associated with haplotypes affecting fertility in Holstein cattle

\begin{tabular}{|c|c|c|c|c|c|c|}
\hline \multirow{2}{*}{ Haplotype } & \multirow{2}{*}{ OMIA IL } & \multicolumn{2}{|r|}{ Gene } & \multicolumn{2}{|c|}{ Polymorphism } & \multirow{2}{*}{ Ref. } \\
\hline & & symbol & name (defect) & position & type & \\
\hline$\overline{\mathrm{HCD}}$ & 001965 & $A P O B$ & $\begin{array}{l}\text { Apolipoprotein B (cholesterol deficiency; cho- } \\
\text { lesterol deficiency haplotype, CDH) }\end{array}$ & 77.958 .994 & $\begin{array}{l}1,3 \mathrm{~kb} \text { Ins } \\
(\mathrm{G} 135 \mathrm{Vfs} 10 \mathrm{X})\end{array}$ & {$[38-40]$} \\
\hline HHO & 000151 & FANCI & $\begin{array}{l}\text { Fanconi anemia, complementation group I } \\
\text { (brachyspina syndrome, BY) }\end{array}$ & $\begin{array}{l}21.184 .869- \\
21.188 .198\end{array}$ & (V877Lfs27X) & {$[22,41]$} \\
\hline HH1 & 000001 & $A P A F 1$ & Apoptic protease-activating factor 1 & 63.150 .400 & $\begin{array}{l}\mathrm{C} \rightarrow \mathrm{T} \\
(\mathrm{Q} 579 \mathrm{X})\end{array}$ & \\
\hline $\mathrm{HH} 2$ & 001823 & - & - & $\begin{array}{l}94.860 .836- \\
96.553 .339\end{array}$ & - & {$[25,43]$} \\
\hline HH3 & 001824 & $S M C 2$ & $\begin{array}{l}\text { Structural maintenance of chromosomes pro- } \\
\text { tein } 2\end{array}$ & 95.410 .507 & $\begin{array}{l}\mathrm{T} \rightarrow \mathrm{C} \\
(\mathrm{F} 1135 \mathrm{~S})\end{array}$ & {$[43,44]$} \\
\hline HH4 & 001826 & GART & Glycinamide ribonucleotide formyltransferase & 1.277.227 & $\begin{array}{l}\mathrm{A} \rightarrow \mathrm{C} \\
(\mathrm{N} 290 \mathrm{~T})\end{array}$ & \\
\hline HH5 & 001941 & TFB1M & Mitochondrial transcription factor B1 & $\begin{array}{l}93.232 .651- \\
93.370 .998\end{array}$ & $138 \mathrm{~kb}$ Del & {$[27,45]$} \\
\hline НHB & 000595 & $I T G B 2$ & $\begin{array}{l}\beta \text {-Integrin [bovine leukocyte adhesion deficiency, } \\
\text { BLAD] }\end{array}$ & 145.119 .004 & $4 \mathrm{~A} \rightarrow \mathrm{G}$ & [20] \\
\hline $\mathrm{HHC}$ & 001340 & $S L C 35 A 3$ & $\begin{array}{l}\text { Solute carrier family } 35 \text { member A3 (complex } \\
\text { vertebral malformation, CVM) }\end{array}$ & 43.411 .473 & $\begin{array}{l}\mathrm{G} \rightarrow \mathrm{T} \\
(\mathrm{V} 180 \mathrm{~F})\end{array}$ & [21] \\
\hline HHD & 000262 & $U M P S$ & $\begin{array}{l}\text { Uridine monophosphate synthase (deficiency } \\
\text { of uridine monophosphate synthase, DUMPS) }\end{array}$ & 69.757 .801 & $\begin{array}{l}\mathrm{T} \rightarrow \mathrm{C} \\
(\mathrm{R} 1247 \mathrm{X})\end{array}$ & [19] \\
\hline
\end{tabular}

The HCD haplotype that causes young calves to die within weeks to months after birth as a consequence of the onset of idiopathic diarrhea was mapped to chromosome 11 [38]. The HCD is caused by a 1299 bp transposable LTR element (ERV2-1) insertion after genome position $77,958,994$ on BTA11 (UMD3.1), located between nucleotides 24 and 25 of APOB (APOB, apolipoprotein B) exon 5 [39]. An independent study [40] confirmed the localization of the mutation, however, the full length of the endogenous retroviral element (BoERV) insertion was estimated to be approximately $7 \mathrm{~kb}$. The insertion results in a frameshift beginning with amino acid residue 135 in the bovine APOB protein sequence (Gly135ValfsX10) and leads to a $97 \%$ truncation of the corresponding 4567 amino acid long protein. The APOB (apolipoprotein B) is a major member in the apolipoprotein system, representing an essential component of low-density lipoproteins and chylomicrons. The identified defect is similar to inherited familial hypobetalipoproteinemia-1 (FHBL1) in humans (OMIM № 615558), which is characterized by hypocholesterolemia and malabsorption of lipid-soluble vitamins leading to retinal degeneration.

The HH0 haplotype associated with stillbirth was mapped in the 20-25 $\mathrm{Mb}$ region on chromosome 21 [25]. An association has been established between the $\mathrm{HH} 0$ haplotype and a $3.3 \mathrm{~Kb}$ deletion in the FANCI (Fanconi anemia complementation-group I) gene, including exons 25-27 of the 37 and introns 25 and 26 and partially introns 24 and 27 [41]. FANCI is essential in maintaining chromosomal stability. Binding specifically both with single-stranded and double-stranded DNA, the protein participates in activation during the $S$ and $\mathrm{G}_{2}$ phases of the cell cycle. FANCI plays an important role in the repair of DNA double-strand breaks through homologous recombination, as well as in the repair of interstrand crosslinks (ICL). A mutation in the FANCI gene in cattle causes disturbances of embryonic development manifested by the reduction of fetal weight, growth disorders, vertebral deformities in the form of spine shortening and limb lengthening. In addition, congenital anomalies of the internal organs, 
especially the heart, kidneys and gonads are observed.

The HH1 haplotype associated with fetal mortality at different stages of pregnancy was mapped on chromosome 5 in the $58-66 \mathrm{Mb}$ region $[25,26]$. It has been established that $\mathrm{HH} 1$-associated reduced fertility is caused by $\mathrm{C} \rightarrow \mathrm{T}$ nonsense mutation in the apoptotic peptidase-activating factor 1 [APAF1] gene, leading to a Gln Stop substitution at amino acid sequence position 579 [42]. APAF1 functional peptide initiates apoptosis and is essential for normal embryonic development [46].

Haplotype $\mathrm{HH} 2$, which causes death of the fetus in the period up to day 100 of pregnancy, was mapped in the $92-97 \mathrm{Mb}$ region on chromosome 1 [25]. Later, the location for $\mathrm{HH} 2$ was specified between positions 94,860,836 and 96,553,339 [43], but the exact location of the mutation has not yet been established.

Haplotype $\mathrm{HH} 3$, which causes embryonic mortality in the period up to day 60 of pregnancy, was mapped in the 90-95 Mb region on chromosome 8 [25]. According to updated information, the localization of $\mathrm{HH} 3$ is the 94-96 $\mathrm{Mb}$ region [26], its association has been established with a mutation in the structural maintenance of chromosomes 2 gene $(S M C 2)$, also known as chromosomeassociated polypeptide $\mathrm{E}$ [30]. HH3 is caused by a non-synonymous $\mathrm{T} \rightarrow \mathrm{C}$ substitution at position 95,410,507 within exon 24 of SMC2 leading to an amino acid change Phe $\rightarrow$ Ser at position 1135 within the NTPase domain of the encoded protein [43, 44, 47]. As a subunit of condensins I and II, SMC2 contributes to DNA repair, chromosome condensation and segregation during cell division [48].

Haplotype HH4 leading to fetal death (at unknown stage) was localized on chromosome 1 in the $1.9-3.3 \mathrm{Mb}$ region [26]. It was found that haplotype HH4 is consistent with a missense mutation $\mathrm{A} \rightarrow \mathrm{C}$ at position 1,277,227 in the glycinamide ribonucleotide formyltransferase (GART) gene, leading to the amino acid Asn $\rightarrow$ Thr substitution at position 290 [26]. GART is a trifunctional peptide, which plays an important role in the formation of purine through the de novo purine biosynthesis pathway [49] and is essential for normal embryonic development.

Haplotype HH5, causing embryonic losses in the period up to two months of pregnancy, was mapped on chromosome 9 [25] at position 92,350,052-93,910,957 [27]. It has been established that the cause of HH5associated fetal mortality is a $138 \mathrm{~kb}$ deletion (break and merging points, respectively, at positions and 93,232,651 and 93,370,998 UMD_3.1). At sites adjacent to the breaks on both sides, duplicate elements were found, i.e. a member of the Bov-B (upstream) family and L1ME3 of the L1 LINE (downstream) family. Based on this, it was concluded that the mutational event occurred as a result of homologous recombination/deletion. The deletion affects complete sequence of the dimethyladenosine transferase 1 gene, also known as mitochondrial transcription factor B1 (TFB1M) [45]. TFBM1 is required for protein translation initiation in the mitochondria, therefore, its lack in animals, homozygous for the mutation, causes a lethal effect.

The method of homozygosity mapping was used to confirm the associations between haplotype HHB (localized in the 141-146 $\mathrm{Mb}$ region on chromosome 1), HHC (40-46 Mb on chromosome 3) and HHD (55-73 Mb on chromosome 1) with previously discovered hereditary defects, such as, respectively, bovine leukocyte adhesion deficiency (BLAD), complex vertebral malformation (CVM) and deficiency of uridine monophosphate synthase (DUMPS) [25].

The cause of BLAD is known to be an $A \rightarrow G$ substitution at position 383 of the $\beta$-Integrin (integrin beta 2, ITGB2) gene, resulting in an amino acid replacement Asp $\rightarrow$ Gly [20]. ITGB is a membrane protein being a component of heterodimer surface glycoprotein consisting of $\alpha$ and $\beta$ subunits, which is required for platelet aggregation. Integrins exert their effects on ontogeny, hemostasis, 
thrombosis, wound healing, tumor metastasis, as well as the immune defense. A mutation in $I T G B$ leads to disturbances in the interaction between $\beta$-subunit and $\alpha$-subunits, which hampers white blood cells to penetrate from the blood stream to the site of infection [50], thereby impairing the body's immune defenses.

The molecular cause of CVM is a missense mutation $\mathrm{G} \rightarrow \mathrm{T}$ in a solute carrier family 35 member 3 gene (SLC35A3), resulting in an amino acid substitution Val $\rightarrow$ Phe at position 180 [51]. SLC35A3 (UDP-N-acetylglucosamine, UDP-GlcNAc transporter), also known as DKFZp781P1297, is responsible for transport of UDP-N-acetylglucosamine in the Golgi complex. A mutation in the SLC35A3 gene impairs its functions. Data obtained from 62,062 inseminations using bulls, who were hidden carriers of the mutation, and their daughters, showed that the majority $(77 \%)$ of fetal carriers resorbed or died in the period up to 260 days of pregnancy, while abortion may occur at any pregnancy term [52]. The rest of pregnancies end in stillbirth usually 1-2 weeks before the expected date of calving. Only a small proportion of calves homozygous for CVM are born alive, however, they soon die too. Characteristic features found in calves carriers are general immaturity, shortened neck, fused or deformed vertebrae and scoliosis. Also, there may be joint deformities in the front and hind limbs. Moreover, heart valve disease was identified in full-term stillborn calves. Thus, 61 (98.4\%) of 62 fetuses with CVM and stillborn calves were diagnosed with spinal injury identified using radiography, and among them there were 58 cases $(93.5 \%)$ of defects of ribs. Heart valve disease, mainly in the form of dysplasia, was present in 15 cases $(24.2 \%)$. Bilateral symmetrical curvature of carpal and metacarpal joints was found in all cases, while the late arthritis was diagnosed in 54 cases $(87.1 \%)$. Ventricular septum defect was observed in 33 cases $(53.2 \%)$, often concurrent to other cardiac defects [53].

DUMPS arises from a nucleotide substitution $\mathrm{T} \rightarrow \mathrm{C}$ at position 1247 of the uridine monophosphate synthase $(U M S)$ gene, resulting in an amino acid substitution Arg $\rightarrow$ Stop [54]. In animals carriers, a truncated protein with altered biological functions is synthesized instead of a normal length protein. UMS is an enzyme responsible for converting orotic acid to uridine monophosphate that serves as a component of pyrimidine nucleotides. Homozygosity for the mutant allele results in the intrauterine death of the embryo in the period up to day 40 of pregnancy, thus exerting a negative effect on fertility $[55,56]$.

The pedigree analysis of 560 sires, used in the system of artificial insemination in Russia, and evaluation of their status based on the search in the database of Holstein cattle [57] demonstrated that the percentage of bulls, whose fathers were hidden carriers of haplotypes affecting fertility, amounts up to $5.4 \%$. To reduce genetically associated embryonic and early post-embryonic losses, it is required to control the spread of haplotypes affecting fertility in the Russian population of Holstein and Holsteinized cattle.

For this purpose, the Center for Biotechnology and Molecular Diagnostics at L.K. Ernst All-Russian Research Institute for Animal Husbandry (Dubrovitsy, Moscow Province) performs genetic monitoring of LoF-mutations in $A P O B, F A N C I, A P A F 1, S M C 2$, GART, TFBM1, ITGB2, SLC35A3, UMPS genes, which are associated, respectively, with HCD, BY, HH1, HH3, HH4, HH5, BLAD, CVM and DUMPS [58-61].

Screening for hidden carriers of the above genetic defects among domestic Holstein and Holsteinized Black Pied cattle showed that they occur at a relatively high rate, which amounts up to about $10 \%$ in cows and about $4 \%$ in sires.

Implementation of DNA diagnostics allows to control the spread of mutations that determine hereditary defects in the population of breeding cattle and gradually eliminate them. Thus, in the first 1-2 years of genetic monitoring 
among sires, more than $5 \%$ hidden CVM carriers were diagnosed, as well as about $3 \%$ hidden BLAD carriers, while currently the corresponding mutant alleles in the studied population of sires are absent [62, 63].

Thus, a new approach called homozygosity mapping has enabled identifying in cattle breeds the genome regions associated with fetal and early postembryonic mortality, which were designated as haplotypes affecting fertility. Currently, 10 lethal haplotypes are registered in Holstein cattle. Due to their extensive spread in populations of breeding cattle, haplotypes affecting fertility and underlying LoF-mutations are one of the major reasons for the decreased fertility in cows. Considering the exponential growth of investigations on structural and functional genomics of animals, particularly cattle, new genetic defects can be expected to be discovered in the near future. Therefore, DNA diagnostics will become an effective tool in monitoring and managing the risks arising from the spread of genetic defects in populations of breeding animals.

\section{REFEREN C ES}

1. Domestic animal diversity database (DAD-IS). Available http://dad.fao.org/. Accessed February 27, 2016.

2. Lab i n o v V.V. Rezul'taty i osnovnye napravleniya sovershenstvovaniya selektsionno-plemennoi raboty v molochnom skotovodstve Rossiiskoi Federatsii. Ministerstvo sel'skogo khozyaistva RF [Advances and main aspects of improved breeding in livestock husbandry in the Russian Federation]. Available http://www.mcx.ru/documents/file_document/v7_show/33370.133.htm. Accessed May 28, 2016 (in Russ.).

3. Barbat A., Le Mezec P., Ducrocq V., Mattalia S., Fritz S., Boichard D., Ponsart C., Humblot P. Female fertility in French dairy breeds: current situation and strategies for improvement. J. Reprod. Dev., 2010, 56: S15-S21 (doi: 10.1262/jrd.1056S15).

4. Washburn S.P., S ilvia W.J., B rown C.H., M c Daniel B.T., Mc Alliste r A.J. Trends in reproductive performance in Southeastern Holstein and Jersey DHI herds. J. Dairy Sci., 2002, 85: 244-251 (doi: 10.3168/jds.S0022-0302(02)74073-3).

5. Lu c y M.C. Reproductive loss in high-producing dairy cattle: where will it end? J. Dairy Sci., 2001, 84: 1277-1293 (doi: 10.3168/jds.S0022-0302(01)70158-0).

6. Silvi a W. Changes in reproductive performance of Holstein dairy cows in Kentucky from 1972 to 1996. J. Dairy Sci., 1998, 81(Suppl. 1): 244.

7. Sub b ot i n A.D. Zhivotnovodstvo Rossii, 2011, 10: 45-46 (in Russ.).

8. Dobson H., S mith R.F., Royal M.D., Knight C.H., Sheldon I.M. The high producing dairy cow and its reproductive performance. Reprod. Domest. Anim., 2007, 42(Suppl 2): 17-23 (doi: 10.1111/j.1439-0531.2007.00906.x).

9. Olte n a c u P.A., B r o o m D.M. The impact of genetic selection for increased milk yield on the welfare of dairy cows. Animal Welfare, 2010, 19(S): 39-49.

10. D u rbi n R.M., the 1000 Genomes Project Consortium. A map of human genome variation from population-scale sequencing. Nature, 2010, 467: 1061-1073 (doi: 10.1038/nature09534).

11. Pelak K., Shianna K.V., Ge D., Maia J.M., Zhu M., S mith J.P., Cirulli E.T., Fellay J., Dickson S.P., Gumbs C.E., Heinzen E.L., Need A.C., Ruz zo E.K., Singh A., Campbell C.R., Hong L.K., Lornsen K.A., McKenzi e A.M., Sobreira N.L., Hoover-Fong J.E., Milner J.D., Ottman R., H a y nes B.F., G o e d e r t J.J., Gold ste i n D.B. The characterization of twenty sequenced human genomes. PLoS Genet., 2010, 6(9): e1001111 (doi: 10.1371/journal.pgen.1001111).

12. MacArthur D.G., B alasubramanian S., Frankish A., Huang N., Morris J., Walter K., J o st ins L., H abegger L., P i ckrell J.K., Montgome ry S.B., Albers C.A., Zhang Z.D., Conrad D.F., Lunter G., Zheng H., Ayub Q., De Pristo M.A., Banks E., Hu M., Handsaker R.E., Rosenfeld J.A., Fromer M., Jin M., Mu X.J., Khurana E., Ye K., Kay M., S a unders G.I., Sune r M.M., Hunt T., Barnes I.H., Amid C., Carvalho-Silva D.R., Bigne 11 A.H., Snow C., Yngvadottir B., Bumpstead S., Cooper D.N., Xue Y., Ro me ro I.G., the 1000 Genomes Project Consortium, Wang J., Li Y., Gibbs R.A., M c Carroll S.A., Dermitzakis E.T., Pritchard J.K., B arrett J.C., Harrow J., Hurles M.E., Gerstein M.B., Tyle r-S mith C. A systematic survey of loss-of-function variants in human protein-coding genes. Science, 2012, 335: 823-828 (doi: 10.1126/science.1215040).

13. B ickhart D.M., Hou Y., Schroeder S.G., Alkan C., Cardone M.F., Ma tukumalli L.K., Song J., Schnabel R.D., Ventura M., Taylor J.F., Gar- 
c i a J.F., Van Tasse 11 C.P., Sonstegard T.S., Ei chler E.E., Liu G.E. Copy number variation of individual cattle genomes using next-generation sequencing. Genome Res., 2012, 22(4): 778-790 (doi: 10.1101/gr.133967.111).

14. Council on dairy cattle breeding. Inbreeding trend for holstein or red \& white cows. Available https://www.cdcb.us/eval/summary/inbrd.cfm? Accessed February 27, 2016.

15. K u z n e t s o v V.M., V a k ho n i n N.V. Sel'skokhozyaistvennaya biologiya [Agricultural Biology], 2010, 4: 55-58 (in Russ.). Available http://www.agrobiology.ru/4-2010kuznetsov.html. No date.

16. We ige 1 K.A. Controlling inbreeding in modern breeding programs. J. Dairy Sci., 2001, 84(Suppl. E): E177-E184.

17. S t o l p ovski i Yu.A. Concept and principles of genetic monitoring for the purpose of preservation in situ of domestical animals kinds. Agricultural Biology, 2010, 6: 3-8 (in Engl.). Available http://www.agrobiology.ru/6-2010stolpovskiy-eng.html. No date.

18. M a r zanov N.S., D evrishov D.A., M a rza nova S.N., Ko m kova E.A., Oze rov M.Yu., Ka n t a n e n Yu. Sel'skokhozyaistvennaya biologiya [Agricultural Biology], 2011, 2: 3-14 (in Russ.). Available http://www.agrobiology.ru/2-2011marzanov.html. No date.

19. Shanks R.D., Do mb rowski D.B., Harpestad G.W., Robi nso n J.L. Inheritance of UMP synthase in dairy cattle. J. Hered., 1984, 75: 337-340.

20. Shuster D.E., Kehrli Jr. M.E., A ckermann M.R., G ilbert R.O. Identification and prevalence of a genetic defect that causes leukocyte adhesion deficiency in Holstein cattle. PNAS USA, 1992, 89: 9225-9229 (doi: 10.1073/pnas.89.19.9225).

21. Agerholm J.S., B e ndixen C., Andersen O., A r n bje rg J. Complex vertebral malformation in Holstein calves. J. Vet. Diagn. Invest., 2001, 13: 283-289 (doi: 10.1177/104063870101300401).

22. Age rh o $1 \mathrm{~m}$ J.S., M c Ev y F., A r n bje rg J. Brachyspina syndrome in a Holstein calf. $J$. Vet. Diagn. Invest., 2006, 18: 418-422 (doi: 10.1177/104063870601800421).

23. Georges M., Diet $\mathrm{Z}$ A.B., Mishra A., Niels en D., S a rgeant L.S., Sorense n A., S t e e le M.R., Z ha o X., Le i p old H., W o mack J.E. Microsatellite mapping of the gene causing weaver disease in cattle will allow the study of an associated quantitative trait locus. PNAS USA, 1993, 90: 1058-1062 (doi: 10.1073/pnas.90.3.1058).

24. Charlier C., Coppieters W., Rollin F., Desmecht D., Agerholm J.S., Cambisano N., Carta E., Dardano S., Dive M., F a squelle C., Frennet J.C., Hanset R., Hubin X., Jorgensen C., Karim L., Kent M., Harvey K., Pearce B.R., Simon P., Tama N., Nie H., Vandeputte S., Lien S., Longeri M., Fredholm M., Harvey R.J., Georges M. Highly effective SNPbased association mapping and management of recessive defects in livestock. Nat. Genet., 2008, 40: 449-454 (doi: 10.1038/ng.96).

25. Van Rade n P.M., O ls o n K.M., Null D.J., Hutch is o n J.L. Harmful recessive effects on fertility detected by absence of homozygous haplotypes. J. Dairy Sci., 2011, 94: 61536161 (doi: 10.3168/jds.2011-4624).

26. Fritz S., Capitan A., Djari A., Rodriguez S.C., Barbat A., Baur A., Grohs C., Weiss B., Boussaha M., Esquerré D., Klopp C., Rocha D., $\mathrm{B}$ o i chard D. Detection of haplotypes associated with prenatal death in dairy cattle and identification of deleterious mutations in GART, SHBG and SLC37A2. PLoS ONE, 2013, 8(6): e65550 (doi: 10.1371/journal.pone.0065550).

27. Cooper T.A., Wiggans G.R., Van Raden P.M., Hutchison J.L., Cole J.B., $\mathrm{Nu} 11$ D.J. Genomic evaluation of Ayrshire dairy cattle and new haplotypes affecting fertility and stillbirth in Holstein, Brown Swiss and Ayrshire breeds. JAM, 2013, T206.

28. Sonst egard T.S., Cole J.B., Van Raden P.M., Van Tasse 11 C.P., N u 11 D.J., $\mathrm{S}$ chroeder S.G., B i ck hart D., M c Clure M.C. Identification of a nonsense mutation in CWC15 associated with decreased reproductive efficiency in Jersey cattle. PLoS ONE, 2013, 8: e54872 (doi: 10.1371/journal.pone.0054872).

29. McClure M., Kim E., Bickhart D., Null D., Cooper T., Cole J., Wiggans G., Ajmone-Marsan P., Colli L., Santus L., Liu G.E., Schroeder S., Mat u k u a 11 i L., Van Tas se 11 C., Sonstegard T. Fine mapping for Weaver syndrome in Brown Swiss cattle and the identification of 41 concordant mutations across NRCAM, PNPLA8 and CTTNBP2. PLoS ONE, 2013, 8(3): e59251 (doi: 10.1371/journal.pone.0059251).

30. Pausch H., Schwarzenbacher H., Burgstaller J., Flisikowski K., Wurmser C., Jansen S., Jung S., S chnieke A., Wit te k T., Fri es R. Homozygous haplotype deficiency reveals deleterious mutations compromising reproductive and rearing success in cattle. BMC Genomics, 2015, 16: 312 (doi: 10.1186/s12864-015-1483-7).

31. Kadri N.K., Sahana G., Charlier C., I so-Touru T., Guldbrandtsen B., Karim L., Niels en U.S., Panitz F., A a mand G.P., Schulman N., Georges M., Vilk ki J., Lund M.S., D ru et T. A 660-Kb deletion with antagonistic effects on fertility and milk production segregates at high frequency in Nordic Red cattle: additional evidence for the common occurrence of balancing selection in livestock. PLoS Genet., 2014, 10(1): e1004049 (doi: 10.1371/journal.pgen.1004049). 
32. Cole J.B., Van Raden P.M., Null D.J., Hutchison J.L., Cooper T.A., Hub $\mathrm{b}$ a $\mathrm{rd}$ S.M. Haplotype tests for recessive disorders that affect fertility and other traits. AIP Research Report Genomic3, 02. Feb. 2016. Available http://aipl.arsusda.gov/reference/recessive_haplotypes_ARRG3.html. Accessed February 09, 2016.

33. Ols o n T. New genes: good and bad. Available http://dairy.ifas.ufl.edu/dpc/2002/Olson.pdf. Accessed March 02, 2016.

34. Vi e rhout C.N., C a s s e 11 B.G., P e a r s o n R.E. Comparisons of cows and herds in two progeny testing programs and two corresponding states. J. Dairy Sci., 1999, 82: 822-828 (doi: $10.3168 /$ jds.S0022-0302(99)75302-6).

35. Larkin D.M., Da etwyle r H.D., Hernandez A.G., Wright C.L., Het r i ck L.A., B oucek L., B a chman S.L., B a nd M.R., Akraiko T.V., CohenZinder M., Thi m ma puram J., M a cleod I.M., H a rkins T.T., M c Cague J.E., Godd a rd M.E., H a y e s B.J., Lew i n H.A. Whole-genome resequencing of two elite sires for the detection of haplotypes under selection in dairy cattle. PNAS USA, 2012, 109(20): 7693 7698 (doi: 10.1073/pnas.1114546109).

36. Holstein sire Jocko Besne Passes. Holstein World, 2012. Available http://www.holsteinworld.com/story.php?id=6044\#sthash.5tNGTcW4.dpbs. Accessed March 02, 2016.

37. Kuhn M., Hutchis on J., Van Tass e 11 C. Effects of complex vertebral malformation gene on production and reproduction. J. Anim. Sci., 2005, 83(Suppl. 1): 140.

38. Kipp S., Segelke D., Schierenbeck S., Reinhardt F., Reents R., Wurmse r C., Pausch H., Fries R., Thaller G., Tetens J., Pott J., Piechotta M., G r ü n b e rg W. A new Holstein haplotype affecting calf survival. Interbull Bull., 2015, 49: 49-53.

39. Menzi F., Besuchet-Schmutz N., Fragnière M., Hofstetter S., Jagannathan V., Mock T., Raemy A., Studer E., Mehinagic K., Regensche it N., Meylan M., S chmitz-H su F., D röge mülle r C. A transposable element insertion in APOB causes cholesterol deficiency in Holstein cattle. Anim. Genet., 2016, 47(2): 253-257 (doi: 10.1111/age.12410).

40. $\mathrm{C}$ h a rli e r C. The role of mobile genetic elements in the bovine genome. Proc. Plant and Animal Genome XXIV Conf. San Diego, 2016: W636.

41. Charlier C., Agerholm J.S., Coppieters W., Karlskov-Mortensen P., Li W., de Jong G., Fasquelle C., Karim L., Cirera S., Cambisano N., Ahariz N., Mullaart E., Georges M., Fredholm M. A deletion in the bovine FANCI gene compromises fertility by causing fetal death and brachyspina. PLoS ONE, 2012, 7(8): e43085 (doi: 10.1371/journal.pone.0043085).

42. Ada m s H.A., S onstegard T., Van Raden P.M., Null D.J., Van Tasse 11 C., Le wi n H. Identification of a nonsense mutation in APAF1 that is causal for a decrease in reproductive efficiency in dairy cattle. Proc. Plant and Animal Genome XX Conf. San Diego, 2012: P0555.

43. McClure M.C., Bickhart D., Null D., Van Raden P., Xu L., Wiggans G., Liu G., Schroeder S., Glasscock J., Armstrong J., Cole J.B., Van Tas s e 11 C.P., S o n st e g a r d T.S. Bovine exome sequence analysis and targeted SNP genotyping of recessive fertility defects $\mathrm{BH} 1, \mathrm{HH} 2$ and $\mathrm{HH} 3$ reveal causative mutation in SMC2 for $\mathrm{HH} 3$. PLoS ONE, 2014, 9: e92769 (doi: 10.1371/journal.pone.0092769).

44. Daetwyler H.D., Capitan A., Pausch H., S tothard P., van Binsbergen R., Brøndum R.F., Liao X., Djari A., Rodriguez S.C., Grohs C., Es querré D., Bouchez O., Rossignol M.-N., Klopp C., Richa D., Fritz S., Eggen A., B ow man P.J., Coote D., Chamberlain A.J., Anderson C., Van Tasse 11 C.P., Hulsegge I., Goddard M.E., Guldbrandtsen B., Lund M.S., Ve e rk a m p.F., B o i c hard D.A., Fries R., H a y s B.J. Whole-genome sequencing of 234 bulls facilitates mapping of monogenic and complex traits in cattle. Nature Genet., 2014, 46: 858-865 (doi: 10.1038/ng.3034).

45. Schütz E., Wehrhahn C., Wanjek M., Bortfeld R., We mheuer W.E., Beck J., B re nig B. The Holstein Friesian lethal haplotype 5 (HH5) results from a complete deletion of TBF1M and cholesterol deficiency (CDH) from an ERV-(LTR) insertion into the coding region of APOB. PLoS ONE, 2016, 11(4): e0154602 (doi: 10.1371/journal.pone.0154602).

46. D e Zi o D., Maiani E., C e c c o n i F. Apaf1 in embryonic development - shaping life by death, and more. Int. J. Dev. Biol., 2015, 59(1-3): 33-39 (doi: 10.1387/ijdb.150047dd).

47. Hayes B., Daetwyle r H.D., Fries R., Guldbrandtsen B., Lund M.S., B o i chard D.A., S t o thard P., Ve e rka mp R.F., H u ls egge I., Rocha D., Van Tas se 11 C., Mulla art E., Gredle r B., Druet T., Bagnato A., Goddard M., $\mathrm{Ch}$ a m b e rlai n A., 1000 Bull Genomes Consortium. The 1000 Bull Genomes project - toward genomic selection from whole genome sequence data in dairy and beef cattle. Proc. Plant and Animal Genome XXI Conf. San Diego, 2013: W150.

48. Schmiesing J.A., Ball A.R. Jr., Gregson H.C., Alderton J.M., Zhou S., Y o k o mo r i K. Identification of two distinct human SMC protein complexes involved in mitotic chromosome dynamics. PNAS USA, 1998, 95(22): 12906-12911 (doi: 10.1073/pnas.95.22.12906).

49. Ng A., U ribe R.A., Y i e h L., Nuckels R., G ros s J.M. Zebrafish mutations in gart 
and paics identify crucial roles for de novo purine synthesis in vertebrate pigmentation and ocular development. Development, 2009, 136(15): 2601-2611 (doi: 10.1242/dev.038315).

50. $\mathrm{N}$ a g a h a t a H. Bovine leukocyte adhesion deficiency (BLAD): a review. J. Vet. Med. Sci., 2004, 66: 1475-1482 (doi: 10.1292/jvms.66.1475).

51. Thomsen B., Horn P., Panitz F., Bendixen E., Petersen A.H., Holm L.E., $\mathrm{N}$ i e $1 \mathrm{~s}$ e n V.H., Age rholm J.S., A r nbjerg J., B e ndixe n C. A missense mutation in the bovine $S L C 35 A 3$ gene, encoding a UDP-N-acetylglucosamine transporter, causes complex vertebral malformation. Genome Res., 2006, 16: 97-105 (doi: 10.1101/gr.3690506).

52. Nielsen U.S., A a mand G.P., Andersen O., B endixen C., Nie lsen V.H., Ag e rho $1 \mathrm{~m}$ J.S. Effects of complex vertebral malformation on fertility traits in Holstein cattle. Livestock Production Science, 2003, 79: 233-238 (doi: 10.1016/S0301-6226(02)00170-7).

53. Agerholm J.S., Andersen O., Almskou M.B., Bendixen C., Arnbjerg J., A a mand G.P., Niels en U.S., Panitz F., Peterse $n$ A.H. Evaluation of the inheritance of the complex vertebral malformation syndrome by breeding studies. Acta Vet. Scand., 2004, 45: 133-137.

54. S $\mathrm{ch}$ we $\mathrm{n}$ ge r B., S c h öb e r S., S i m o n D. DUMPS cattle carry a point mutation in the uridine monophosphate synthase gene. Genomics, 1993, 16(1): 241-244 (doi: 10.1006/geno.1993.1165).

55. S h a n k s R.D., R o bi n s o n J.L. Embryonic mortality attributed to inherited deficiency of uridine monophosphate synthase. J. Dairy Sci., 1989, 72(11): 3035-3039 (doi: 10.3168/jds.S0022-0302(89)79456-X).

56. Shanks R.D., P op p R.G., M c Coy G.C., N e ls o n D.R., Robi n so n J.L. Identification of the homozygous recessive genotype for the deficiency of uridine monophosphate synthase in 35-day bovine embryos. J. Reprod. Fertil., 1992, 94(1): 5-10 (doi: 10.1530/jrf.0.0940005).

57. Bulls' status for haplotypes impacting fertility on the records of Holstein Association USA. Holstein Association USA, 14.12.2015. Available http://www.holsteinusa.com/pdf/haplotype/hapbulcarriers.pdf. Accessed March 05, 2016.

58. Z i nov'e va N.A., G la d y r' E.A., E rnst L.K., B re m G. Vvedenie v molekulyarnuyu gennuyu diagnostiku sel'skokhozyaistvennykh zhivotnykh [Introduction to molecular gene diagnosis in farm animals]. Dubrovitsy, 2002 (in Russ.).

59. Romanenkova O.V., Gladyr' E.A., Kostyunina O.V., Zinov'eva N.A. Dostizheniya nauki i tekhniki APK, 2015, 11: 91-94 (in Russ.).

60. Romanenkova O.V., Gladyr' E.A., Kostyunina O.V., Zinov'eva N.A. Dostizheniya nauki i tekhniki APK, 2016, 30(2): 94-97 (in Russ.).

61. Zinov'eva N.A., Kostyunina O.V., Volkova V.V., Yanchukov I.N., Ermilov A.N. Molochnoe i myasnoe skotovodstvo, 2016, 2: 5-7 (in Russ.).

62. Zinov'eva N.A., Gladyr' E.A., Kharzinova V.R., Kostyunina O.V., Pok rovskay a M.V., D rush lyak N.G., Kabitsk y a Ya.A. Dostizheniya nauki $i$ tekhniki $A P K, 2012,11:$ 37-40 (in Russ.).

63. Zinov'eva N.A., Strekozov N.I., Eskin G.V., Turbina I.S., Yanchuk o v I.N., Ermilov A.N. Zhivotnovodstvo Rossii, 2015, 6: 30-31 (in Russ.). 